\title{
Towards The HCi Living Curriculum
}

\author{
Andrea Jovanovic ${ }^{1}$, Olivier St-Cyr ${ }^{2,1}$, and Mark Chignell ${ }^{1}$ \\ ${ }^{1}$ Department of Mechanical and Industrial Engineering \\ ${ }^{2}$ Faculty of Information - iSchool \\ University of Toronto \\ olivier.st.cyr@utoronto.ca
}

\begin{abstract}
The Association of Computing Machinery (ACM) Special Interest Group on Computer-Human Interaction (SIGCHI) has been supporting research into HCI education for many years, most actively in the last six years. At its CHI2014 conference, a workshop on developing a new Human-Computer Interaction (HCI) living curriculum was held, building on three years of research and collaboration. We believe the time is now right to design and build the proposed HCI living curriculum. This paper proposes the preliminary framework for a concrete active social network of HCI scholars and educators, sharing and collaborating to develop course outlines, curricula, and teaching materials. In particular, this paper presents the use cases and design requirements of the HCI living curriculum, based on data collected from HCI educators and practitioners. Future initiatives to move the design forward by prototyping a first version of the living curriculum are also discussed.
\end{abstract}

Keywords: Human-Computer Interaction curriculum; education; design requirements; use cases.

\section{INTRODUCTION}

From 2011-2014, the Association of Computing Machinery (ACM) Special Interest Group on ComputerHuman Interaction (SIGCHI) Executive Committee sponsored a project to investigate the present and future of Human-Computer Interaction (HCI) education [1]. Research has consisted of 52 interviews conducted with SIGCHI community members, as well as 616 surveys completed in English, 156 in Brazilian Portuguese, 52 in Mandarin Chinese, and 48 in Chilean Spanish. Questions focused on what educators, practitioners, and students considered to be top priorities for the field of HCI. Additionally, educational resources were compiled and discussions were hosted at the annual CHI conferences, including discussion lunches, HCI education workshops, and SIGCHI Town Hall meeting discussions [1].
A recurring theme that emerged throughout the project was participants' desire for a collection of online resources shared among HCI educators. The goal formulated was to create a community of practice $(\mathrm{CoP})$ of HCI scholars and educators, sharing and collaborating to develop course outlines, curricula, and teaching material, known as a living curriculum [2]. In order to be effective for the fast moving HCI field, these resources would need to be frequently updated and maintained. Functionality for discussion and commenting would also be essential in supporting the objective of content codevelopment.

The current infrastructure of the SIGCHI HCI Education Community [3] does not support the envisioned communication and sharing of resources. Before the living curriculum can become a reality, there is a need to investigate outside community platforms or methods of extending the current infrastructure.

A workshop on developing the HCI living curriculum was held at the CHI2014 conference [4]. Several visions of what this new curriculum could be were presented. However, as of this writing in 2017, the proposed HCI living curriculum has yet to be designed or implemented.

This paper focuses on the initial design of the HCI living curriculum, defining its most common use cases and essential design requirements, based on interview data collected from HCI scholars and educators. Future initiatives to move the design forward by prototyping a first version of the living curriculum will also be discussed. Our research ultimately aims to (1) firm up design requirements for the HCI living curriculum user experience; (2) articulate the interface, interaction, architecture, and infrastructure for a $\mathrm{CoP}$ of this kind; (3) assess what tools, platforms and services may already be available and to assess their long-term viability and value to the HCI community; and (4) create and evaluate a first prototype of the HCI living curriculum user interface.

The remainder of this paper will present a literature review on CoPs, the methodology we executed to conduct our interviews and collect data, the use cases and requirements of the $\mathrm{HCI}$ living curriculum that were uncovered, and the future steps for our research. While we are primarily targeting educators in the area of $\mathrm{HCI}$ 
education, the scope of this paper is much broader. Indeed, educators who are interested in designing user interfaces for $\mathrm{CoP}$ and/or applying a User-Centered Design (UCD) approach to the design of CoP will most likely find some interests in our research.

\section{BACKGROUND}

A CoP is a group "of people who share a concern, a set of problems, or a passion about a topic, and who deepen their knowledge and expertise in this area by interacting on an ongoing basis" [5]. CoPs are viewed as an inventive way to combine working, learning, and innovating [6]. Learning and knowledge creation occur through socialization, and members of the community often develop a set of shared resources to engage more effectively [7]. A growing number of Open Educational Resources (OER) are being shared, reused, and republished, supporting collaborative teaching and learning $[8,9]$.

As Web 2.0 technologies have increased in popularity, virtual CoPs have incorporated social networking functionalities to increase social transparency and ameliorate interaction $[10,11]$. Some of these functionalities include the means to upload content, communicate with other members, and view member profiles $[12,13]$.

The Wikipedia is perhaps the largest community authored repository on the internet, and has been considered by some to be a CoP although it is a very large and diffuse community that contributes to Wikipedia. As noted by [14], earlier and more focused CoPs include the British Royal Society and authors and editors of the Oxford English Dictionary. A more focused community within the Wikipedia consists of people who contribute to health-related pages. [15] surveyed 32 people who contribute to Wikipedia health pages and interviewed 17 of those people. [15] noted five factors that motivated people in their sample to contribute to Wikipedia health pages: "education (learning about subjects by editing articles), help (wanting to improve and maintain Wikipedia), responsibility (responsibility, often a professional responsibility, to provide good quality health information to readers), fulfillment (editing Wikipedia as a fun, relaxing, engaging, and rewarding activity), and positive attitude to Wikipedia (belief in the value of Wikipedia)." It seems likely that similar motivations might also be applicable to an HCI living curriculum CoP. [15] also noted that "the community who most actively monitor and edit health-related articles is very small" with some community members focusing on "improving spelling and grammar, organization, and handling vandalism".

While much of the motivation for contribution to CoPs seems to be altruistic and intrinsic, feedback mechanisms have been proposed or developed for providing additional external information. For instance [16] cited the Encyclopedia of Life as using featured contributor pages to recognize important contributors. Impact factors of various kinds can also be used. For instance, Research Gate's RG score is a composite metric taking into account social interactions and reputation alongside traditional publication-based metrics [17]. Various forms of badges, awards, and recognitions [18] may also be used to reward and recognize contributions within a CoP.

One concern with any $\mathrm{CoP}$ is sustainability. Community members must be able to see clear benefits from their participation that outweigh any associated costs. Perceived benefits that should enhance sustainability include extrinsic returns such as status, reciprocity, and reputation [19], and intrinsic returns such as enjoyment and social interaction with other community members [20, 21].

Another concern for CoPs is the usability and effectiveness of collaborative writing applications. [22] surveyed the literature on the use of collaborative writing applications in healthcare. They concluded that "More primary research is needed to find ways to address the different barriers to their use and to make these applications more useful for different stakeholders."

CoPs typically publish documents to the entire community, not to the public at large. They generally use an open publishing model where there is no strong organizational ownership of material (e.g., a fairly liberal creative commons type of license is provided, where reuse is permitted as long as there is attribution). [23] examine attitudes towards the rights of authors in a teaching and learning community. In this case, many authors were willing to share their resources with others because of the value that they received from feedback provided and the assistance they got from others in improving the quality of materials.

One of the strongest arguments for participation in a $\mathrm{CoP}$ is skill development. While authorship is not explicitly noted on Wikipedia pages, professional CoPs often have strong role models that may assist people in developing their professional identity (cf. [24]). In a community like the HCI Living Curriculum, participants can expect to view and discuss best practices, thereby honing their skills as HCI educators. [25] discussed this type of professional development in a graphic design community. Activities that they noted as supporting skills development included exposure to others' work and interaction around created artifacts and the observation of role models and imitation of their practices. In addition to role models, more active mentoring may occur in a $\mathrm{CoP}$, either through design, or through serendipitous relationships that occur. Given that many members of the HCI Living Community will be academics it seems likely that the skills and practices that they have developed in mentoring graduate students may also transfer to the community, leading to beneficial mentoring relations that 
should strengthen the community. Informal mentoring in the form of advisory feedback below the threshold of a personal relationship may also occur, as was demonstrated in the case of distributed mentoring within an online fan community [26].

A professional CoP such as the HCI living curriculum needs to ensure that quality is maintained. This can be done by using both technological and social approaches. Social tools include user generated collaborative quality methods such as rating [27], and technological tools that automatically check for indicators of quality reflected in the interface [28].

One final key consideration for a $\mathrm{CoP}$ is how it should be governed and administered (e.g., [29]). For instance, although the Wikipedia does rely on a distributed collection of editors and contributors there is in fact a central governance structure that sets policy and arbitrates disputes where necessary. The hierarchical governance of Wikipedia and some challenges with that structure are discussed by [30].

The preceding review of literature on CoPs highlights some of the key issues that need to be addressed in the HCI Living Curriculum. Clearly there need to be mechanisms for ensuring quality and for motivating and rewarding contributions and discussion. However, the general literature reviewed above does not provide specific guidance for how to develop an HCI living curriculum. For this guidance, we turn to observation of HCI educators and practitioners (in a set of interviews) to understand their expectations and requirements for the $\mathrm{CoP}$ to be implemented as the HCI living curriculum.

\section{METHOD}

Our research aims to investigate the requirements and use cases for the design of the HCI living curriculum. In particular, we were interested in answering the following research questions:

1. How do stakeholders envision a HCI living curriculum?

2. What are the requirements for a HCI living curriculum?

3. What are the barriers to a HCI living curriculum?

To answer these questions, we conducted a qualitative study consisting of a series of individual semi-structured interviews. The goal of the individual interviews was to collect data from HCI practitioners and educators who will be potential end users of the HCI living curriculum CoP. In total, we conducted interviews with 12 participants. Participants were contacted via an announcement in the HCI Education Facebook Group (managed by the second author of this paper). They were selected based on their willingness to participate and were not compensated for their participation. All participants were HCI educators or had been involved in HCI education projects in their professional careers. They consisted of a mix of academics (nine participants) and industry professionals (three participants) from the SIGCHI community representing several regions such as: North America, Africa, Europe, and the Middle East. Interviews took place online using Skype, on the phone, and in person at the CHI2017 Conference in Denver, Colorado, May 6-11, 2017. The first author of this paper conducted the interviews.

\subsection{Procedure}

Each interview lasted 15 minutes to 45 minutes and was conducted using the same procedure. First, the researcher introduced herself to the participant and provided a brief introduction to the study background and procedures. The participant was asked to read a consent form and provide verbal consent. Second, the researcher began the semi-structured interview following a preset guide. A background description of the motivation for a living curriculum in HCI was provided to the participant. The interviewee was then asked a series of questions regarding their opinions about a living curriculum in HCI. The researcher also explored unanticipated themes as they were raised during the session. Below are the initial questions that were used for each interview:

1. How do you envision a HCI living curriculum?

2. What do you think are the requirements for a HCI living curriculum?

a. What would participation look like?

b. How should a living curriculum behave?

3. Do you see any barriers to a HCI living curriculum?

a. Do you have any concerns?

b. Are there obstacles that would discourage you from contributing?

At the conclusion of the interview, the participant was debriefed and thanked for their participation.

\subsection{Data Collection and Analysis}

Interviews were audio recorded and content was transcribed into a computerized database and analyzed to extract common themes and requirements through an affinity diagram (Table 1).

\section{RESULTS}

The transcribed interviews were reviewed and comments made by participants were summarized. When a comment was restated by another participant, the new participant ID was added to a previous card. Comments were then organized into groups to create an affinity 
Table 1: Affinity diagram of summarized interview comments. Each column corresponds to a theme. Each theme outlines some design aspects to consider.

\begin{tabular}{|c|c|c|c|c|c|c|}
\hline Motivation & Quality & Contribution & Copyright & Content & Membership & Others \\
\hline $\begin{array}{l}\text { Barrier to entry could } \\
\text { make participation more } \\
\text { attractive }\end{array}$ & $\begin{array}{l}\text { More concerned about } \\
\text { enactment than content } \\
\text { quality }\end{array}$ & $\begin{array}{l}\text { Co-creation of material like } \\
\text { slides in a Wikipedia style } \\
\text { interaction }\end{array}$ & $\begin{array}{l}\text { Copyright is a reason for } \\
\text { not having open } \\
\text { membership }\end{array}$ & $\begin{array}{l}\text { Framework for } \\
\text { what is important } \\
\text { in the field }\end{array}$ & Institution email required & $\begin{array}{l}\text { Must be very simple to } \\
\text { participate }\end{array}$ \\
\hline $\begin{array}{l}\text { Seeing number of } \\
\text { downloads and where } \\
\text { resources are used is } \\
\text { motivating }\end{array}$ & $\begin{array}{l}\text { Review committee to } \\
\text { ensure high level of } \\
\text { quality }\end{array}$ & $\begin{array}{l}\text { Re-share modified material } \\
\text { originally retrieved from the } \\
\text { system }\end{array}$ & $\begin{array}{l}\text { Concern about not } \\
\text { attributing properly }\end{array}$ & $\begin{array}{l}\text { Information about } \\
\text { how to teach } \\
\text { material }\end{array}$ & $\begin{array}{l}\text { Institutional email not } \\
\text { required }\end{array}$ & $\begin{array}{l}\text { Very quickly changing } \\
\text { field of HCI; broadness of } \\
\text { HCI }\end{array}$ \\
\hline Concern about criticism & $\begin{array}{l}\text { Designated person to } \\
\text { vet material, organize, } \\
\text { and catalogue }\end{array}$ & $\begin{array}{l}\text { Metadata entry should be } \\
\text { simple and optional }\end{array}$ & $\begin{array}{l}\text { Open sharing for } \\
\text { educational purposes; } \\
\text { Creative Commons } \\
\text { licensing }\end{array}$ & $\begin{array}{l}\text { Importance of } \\
\text { pedagogical } \\
\text { practices }\end{array}$ & $\begin{array}{l}\text { Personal profiles for } \\
\text { members }\end{array}$ & $\begin{array}{l}\text { Importance of involving } \\
\text { industry practitioners }\end{array}$ \\
\hline $\begin{array}{l}\text { Gamification and } \\
\text { leaderboards }\end{array}$ & Dislike ratings & $\begin{array}{l}\text { Some may not want to share } \\
\text { their materials }\end{array}$ & & $\begin{array}{l}\text { Suggest topics that } \\
\text { don't have (as } \\
\text { much) material }\end{array}$ & $\begin{array}{l}\text { Ability to create smaller } \\
\text { communities (i.e. around } \\
\text { countries, topics) }\end{array}$ & $\begin{array}{l}\text { Disconnect between } \\
\text { industry and academic }\end{array}$ \\
\hline $\begin{array}{l}\text { Getting credit for } \\
\text { contributing can offset } \\
\text { feeling proprietary }\end{array}$ & $\begin{array}{l}\text { Don't trust ratings from } \\
\text { other people }\end{array}$ & $\begin{array}{l}\text { Social space and commenting } \\
\text { platform where content is } \\
\text { dominant }\end{array}$ & & $\begin{array}{l}\text { Global content and } \\
\text { local content; } \\
\text { different contexts }\end{array}$ & Mentorship opportunities & $\begin{array}{l}\text { Different needs in different } \\
\text { parts of the world }\end{array}$ \\
\hline \multicolumn{2}{|c|}{ Likes/thumbs up can be okay } & $\begin{array}{l}\text { General discussion area (not } \\
\text { based on a material) }\end{array}$ & & & $\begin{array}{l}\text { Commentary given } \\
\text { different weight depending } \\
\text { on experience in HCI }\end{array}$ & $\begin{array}{l}\text { Consider how to handle } \\
\text { multiple languages }\end{array}$ \\
\hline \multicolumn{2}{|c|}{ Likes can be a popularity contest } & \multicolumn{2}{|c|}{$\begin{array}{l}\text { May need to create material from scratch to avoid } \\
\text { attribution and copyright issues }\end{array}$} & & $\begin{array}{l}\text { Participation should not be } \\
\text { anonymous }\end{array}$ & $\begin{array}{l}\text { Importance of involving } \\
\text { industry practitioners }\end{array}$ \\
\hline \multicolumn{2}{|c|}{ Ratings may act as a disincentive } & $\begin{array}{l}\text { Concern about unequal } \\
\text { contributions and } \\
\text { commitment }\end{array}$ & & & & $\begin{array}{l}\text { Disconnect between } \\
\text { industry and academic }\end{array}$ \\
\hline $\begin{array}{l}\text { Institutional buy-in or } \\
\text { accrediting body as } \\
\text { incentive }\end{array}$ & $\begin{array}{l}\text { Reviews including how } \\
\text { resources were used }\end{array}$ & $\begin{array}{l}\text { Different methods of } \\
\text { contribution so that junior } \\
\text { members can also contribute }\end{array}$ & & & & $\begin{array}{l}\text { Some educators are not } \\
\text { very knowledgeable and } \\
\text { are only steps ahead of the } \\
\text { students }\end{array}$ \\
\hline \multirow[t]{4}{*}{$\begin{array}{l}\text { Extra effort such as } \\
\text { following formatting } \\
\text { guides would be } \\
\text { discouraging } \\
\end{array}$} & $\begin{array}{l}\text { Ratings on different } \\
\text { dimensions (such as } \\
\text { HCI content and } \\
\text { pedagogy) }\end{array}$ & $\begin{array}{l}\text { Ability to annotate resources } \\
\text { and see others' annotations }\end{array}$ & & & & $\begin{array}{l}\text { Student engagement } \\
\text { considerations }\end{array}$ \\
\hline & $\begin{array}{l}\text { Tiers of reviews of } \\
\text { materials that are } \\
\text { indicated as being } \\
\text { reviewed }\end{array}$ & $\begin{array}{l}\text { A place to share and ask for } \\
\text { advice }\end{array}$ & & & & \\
\hline & $\begin{array}{l}\text { Once something is } \\
\text { rated it is more likely } \\
\text { to be viewed again }\end{array}$ & $\begin{array}{l}\text { Open contribution from } \\
\text { members }\end{array}$ & & & & \\
\hline & $\begin{array}{l}\text { Diverse or regional } \\
\text { review committee to } \\
\text { incorporate range of } \\
\text { perspectives }\end{array}$ & $\begin{array}{l}\text { Ability to upload drafts and } \\
\text { look for feedback }\end{array}$ & & & & \\
\hline
\end{tabular}


diagram. The groupings that emerged out of our affinity diagram were: motivation, quality, contribution, copyright, content, membership, and others. Some comments overlapped groupings and are indicated by merged cells. Both common (expressed by multiple participants) and uncommon (expressed by only one participant) comments are included in the affinity diagram.

Comments summarized in the affinity diagram range from participants' feelings about contributing to an online community to their beliefs about how features in such a community should be organized and implemented. Comments from the affinity diagram informed the design requirements and use cases outlined below.

\subsection{Design Requirements}

In order to increase motivation to participate in the $\mathrm{CoP}$, the design could display data about use of resources such as number of downloads and who downloaded. Moreover, several participants who were interviewed suggested incorporating some aspects of gamification and leaderboards when uploading resources, contributing to discussions, and reviewing content as well as "likes" or "thumbs up" feature for resources. Authors should also be able to add resources in their current forms without strict formatting constraints.

Quality of the content available in the CoP was also a concern raised by many participants. Some suggested that a review committee be created to oversee resources and to ensure a high level of quality. Members of this review committee should be diverse or possibly regional to incorporate a range of perspectives and acknowledge that HCI can be implemented differently in different global contexts. Moreover, designated administrators should help with organizing and cataloguing material in an appropriate manner. Finally, once resources are available in the CoP, members should be able to leave reviews of the materials by describing how they used the materials and by rating resources on various dimensions (e.g. rating on HCI content quality, rating on pedagogy, etc.).

Several participants provided suggestions regarding the contribution process to the CoP. There should be different ways of contributing to the community and different ways of participating (e.g. a way to encourage junior members to contribute, even if they are not confident in contributing resources). Some also mentioned that metadata entry should be simple and quick to perform, with the option to bypass it. Thus, the contribution process should be as simple as possible. In addition, comments and discussions should be organized around the resources to increase participation and to encourage users to provide feedback related to resources. Finally, contributions could also be made in the form of general discussions. Thus, the CoP should include a general discussion area which is not based on particular resources, but where general topics can be discussed (e.g., a discussion forum to share and ask for advice).

Copyright was a major concern raised by participants in our interviews. To address this issue, all materials and resources should be shared openly for educational purposes, such as using Creative Commons licensing.

Content throughout the community should be based on a framework that is relevant for HCI educators and practitioners. Previous research by Churchill, Bowser, Preece [2] can be used to inform content organization (these authors have already proposed a way to organize HCI education content). Content should not be limited to teaching materials, but should also include information on how to teach the materials and other teaching practices/methods in HCI. Finally, the CoP should support content that is relevant globally as well as content that is relevant only locally in specific contexts.

When it comes to membership, participants in our interviews suggested that members of our $\mathrm{CoP}$ should have personal profiles that are tied to their interaction in the community, such as resources that are uploaded and downloaded, comments that are posted, reviews that are left, etc. They also commented about the ability to incorporate sub-groups or smaller communities (around countries, around subtopics, etc.) within the larger community to provide spaces to discuss specialized and specific needs/topics.

\subsection{Use Cases}

Based on the interview data collected and the requirements outlined in the previous section, a set of preliminary use cases has been developed. An important aspect of these use cases is how contributors will upload resources to the $\mathrm{CoP}$, considered a critical feature by many of our participants. Given that most resources will be tied to academic courses, a course-based framework has been adopted to organize the uploaded resources. This will minimize the amount of metadata that needs to be entered when multiple resources from the same course are uploaded.

\section{Add course}

1. User selects to add course

2. System prompts for course attributes

3. User enters course attributes

4. User selects to save course

5. System adds course

6. System displays course page

\section{Add course item}

1. User selects to add course item

2. System prompts for course item

3. System prompts for course item attributes

4. User selects to save course item

5. System adds course item 
6. System displays course item page

\section{View course}

1. User selects to view course

2. System displays course attributes

3. System displays course items

4. System displays subscription options

5. System displays ratings and discussion information

6. System displays history

\section{Browse}

1. System displays topics

2. User selects topic

3. System displays courses and course items tagged for the selected topic

4. Go to "View results" use case

\section{Search}

1. User selects search bar

2. User enters search criteria

3. User selects to search

4. System display search results

5. Go to "View results" use case

\section{Advanced search}

1. User selects advanced search

2. User enters search criteria

3. User selects any of the advanced search filtering options

4. Go to "View results" use case

\section{View results}

Pre-condition: User has selected a topic to browse, performed a search, or performed an advanced search

1. System displays results grouped by type and sorted by rating

2. User selects a sorting option

3. System displays results sorted by selected option

4. User selects a filtering option

5. System displays results filtered by selected option

\section{CONCLUSION AND FUTURE WORK}

This paper has presented preliminary ideas for a $\mathrm{CoP}$ of HCI scholars and educators with the goals of sharing and collaborating to develop course outlines, curricula, and teaching materials. Through a series of interviews with HCI educators and practitioners, we were able to inform the initial design requirements and use cases for our proposed CoP. Results show that the design of our CoP should incorporate several elements related to the motivation to participate, the quality of the content, the contribution process, the organization of the content, the correct methods for handling copyrights, and membership in the community. Elements related to all these aspects will be carefully examined and integrated in the design of our HCI CoP's user interface.

The next phase of this project will be to fine-tune and finalize all the requirements and use cases presented in this paper. Then, user interface prototypes will be created to present our vision of the HCI living curriculum CoP. These prototypes will be informed by the literature review presented in this paper, a review of platforms and tools available to build CoPs, and the requirements and use cases inferred from our interviews. Third, we will conduct a usability testing evaluation of the prototypes to obtain feedback from representative users (HCI scholars and educators) and to iterate our design ideas. Our final step will be to build a live version of the HCI living curriculum $\mathrm{CoP}$ and pilot its usage with initial content.

\section{Acknowledgements}

We would like to acknowledge and thank the 12 participants who took part in our interviews.

\section{References}

[1] Elizabeth F. Churchill, Anne Bowser, and Jennifer Preece, "Teaching and learning human-computer interaction: past, present, and future," interactions, vol. 20, no. 2, pp. 44-53, 2013.

Available as of May 18, 2017 from

http://dx.doi.org/10.1145/2427076.2427086

[2] Elizabeth F. Churchill, Anne Bowser, and Jennifer Preece, "The future of HCI education: a flexible, global, living curriculum," interactions, vol. 23, no. 2, pp. 70-73, 2016. Available as of May 18, 2017 from http://dx.doi.org/10.1145/2888574

[3] SIGCHI Education Community. http://www.sigchi.org/communities/hci-ed/ Accessed: May 18, 2017

[4] Elizabeth F. Churchill, Jennifer Preece, and Anne Bowser, "Developing a living HCI curriculum to support a global community," in Proc. CHI '14 Extended Abstracts on Human Factors in Computing Systems, CHI EA '14, (Toronto, ON; April 26 - May 1), 4 pp., 2014.

[5] Etienne Wenger, Richard McDermott, and William M. Snyder, Cultivating Communities of Practice: A Guide to Managing Knowledge. Boston, Massachusetts: Harvard Business School Press, 2002, 284 pp. \{ISBN: 978-1-57851$330-7\}$

[6] John Seely Brown and Paul Duguid, "Structure and spontaneity: knowledge and organization", in Ikujiro Nonaka and David J. Teece (eds.), Managing Industrial Knowledge: Creation, Transfer and Utilization. London, England: Sage, 2001, 24 pp. \{ISBN: 9780761954996\} 
[7] Ettore Bolisani and Enrico Scarso, "The place of communities of practice in knowledge management studies: a critical review", Journal of Knowledge Management, vol. 18 no. 2, pp. 366-381, 2014.

Available as of May 17, 2017 from

http://dx.doi.org/10.1108/JKM-07-2013-0277

[8] Kati Clements, Jan Pawlowski, and Nikos Manouselis, "Open educational resources repositories literature review: towards a comprehensive quality approaches framework," Computers in Human Behavior, vol. 51, part B, pp. 10981106, 2015.

Available as of May 17, 2017 from

https://doi.org/10.1016/j.chb.2015.03.026

[9] Yannis Dimitriadis, Patrick McAndrew, Gráinne Conole and Elpida Makriyannis. "New design approaches to repurposing open educational resources for collaborative learning using mediating artefacts," in ascilite 2009: Same places, different spaces, (Auckland, NZ; 6-9 December 2009), 8 pp., 2009.

[10] Jennifer Marlow and Laura Dabbish, "From rookie to allstar: professional development in a graphic design community of practice," in Proc. CSCW, CSCW14, (Baltimore, MD; 15-19 February 2014), 12 pp., 2014.

[11] H. Colleen Stuart, Laura Dabbish, Sara Kiesler, Peter Kinnaird, and Ruogu Kang, "Social transparency in networked information exchange: a theoretical framework," in Proc. CSCW, CSCW12, (Seattle, WA; 11-15 February 2012), 10 pp., 2012.

[12] danah m. boyd and Nicole B. Ellison, "Social network sites: definition, history, and scholarship," Journal of Computer-Mediated Communication, vol. 13, no. 1, pp.210230, 2007.

Available as of May 17, 2017 from

onlinelibrary.wiley.com/doi/10.1111/j.1083-

6101.2007.00393.x/pdf

[13] Adam N. Joinson, "Looking at, looking up or keeping up with people?: motives and use of facebook," in Proc. CHI, CHI08, (New York, NY; 5-10 April, 2008), 10 pp., 2008.

[14] Dan O'Sullivan, Wikipedia: a new community of practice?. Burlington, VT: Ashgate Publishing, 2009, 191 pp. $\{9780754674337\}$

[15] Nuša Farič, \& Henry W. Potts, "Motivations for contributing to health-related articles on Wikipedia: an interview study," Journal of medical Internet research, vol. 16, no. 1), e260, 2014.

Available as of May 17, 2017 from

https://www.ncbi.nlm.nih.gov/pmc/articles/PMC4275502/

[16] Dana Rotman, Kezia Procita, Derek Hansen, Cynthia Sims Parr, \& Jennifer Preece, "Supporting Content Curation Communities: The Case of the Encyclopedia of Life," Journal of the American Society for Information Science and Technology, vol. 63, no. 6, pp. 1092-1107, 2012.

Available as of May 17, 2017 from http://onlinelibrary.wiley.com/doi/10.1002/asi.22633/abstrac $\mathrm{t}$

[17] Katherine Jordan, "Exploring the ResearchGate score as an academic metric: reflections and implications for practice," in Quantifying and Analysing Scholarly Communication on the Web, ASCW15, (Oxford, UK; 30 June 2015), 3 pp., 2015.

[18] Brian J. McInnis, Elizabeth L. Murnane, Dmitry Epstein, Dan Cosley, Gilly Leshed, "One and Done: Factors affecting one-time contributors to ad-hoc online communities," in Proc. of the 19th ACM conference on Computer supported cooperative work \& social computing, CSCW16, (San Francisco, CA; 27 February - 2 March), 15 pp., 2016.

[19] Molly McLure Wasko, and Samer Faraj, "Why should I share? Examining social capital and knowledge contribution in electronic networks of practice?," MIS Quarterly, vol. 29, no. 1, pp. 35-37, 2005.

Available as of May 17, 2017 from

https://www.jstor.org/stable/25148667

[20] Hichang Cho, MeiHui Chen, and Siyoung Chung, "Testing an integrative theoretical model of knowledge-sharing behavior in the context of Wikipedia," Journal of the American Society for Information Science and Technology, vol. 61, no. 6, pp. 1198-1212, 2010.

Available as of May 17 from http://onlinelibrary.wiley.com/doi/10.1002/asi.21316/abstrac $\mathrm{t}$

[21] Khe Foon Hew and Noriko Hara, "Empirical study of motivators and barriers of teacher online knowledge sharing," Educational Technology Research and Development, vol. 55, no. 6, pp. 573-595, 2007. Available as of May 17, 2017 from https://link.springer.com/article/10.1007/s11423-007-9049-2

[22] Patrick M. Archambault, Tom H. van de Belt, Francisco J. Grajales III, Marjan J Faber, Craig E Kuziemsky, Susie Gagnon, Andrea Bilodeau, Simon Rioux, Willianne L. D. M. Nelen, Marie-Pierre Gagnon, Alexis F. Turgeon, Karine Aubin, Irving Gold, Julien Poitras, Gunther Eysenbach, Jan A. M. Kremer, and France Légaré, "Wikis and collaborative writing applications in health care: a scoping review," Journal of medical Internet research, vol. 15, no. 10, e210, 2013.

Available as of May 17, 2017 from

https://www.ncbi.nlm.nih.gov/pubmed/24103318

[23] Melanie Bates, Steve Loddington, Sue Manuel, and Charles Oppenheim, "Attitudes to the rights and rewards for author contributions to repositories for teaching and learning," Research in Learning Technology, vol. 15, no. 1, pp. 67-82, 2007.

Available as of May 17 from

http://dx.doi.org/10.1080/09687760600837066

[24] Nicola Andrew, Dorothy Ferguson, George Wilkie, Terry Corcoran, and Liz Simpson, "Developing professional identity in nursing academics: The role of communities of

CEEA17; Paper 140

University of Toronto; June 4 - 7, 2017 
practice," Nurse Education Today, vol. 29, no. 6, pp. 607-

611, 2009.

Available as of May 17 from

https://www.ncbi.nlm.nih.gov/pubmed/19250718

[25] Jennifer Marlow and Laura Dabbish, "From rookie to allstar: professional development in a graphic design social networking site," in Proc. of the 17th ACM conference on Computer supported cooperative work \& social computing, CSCW14). (Baltimore, MD; 15-19 February, 2014), 13 pp., 2014.

[26] Julie Campbell, Cecilia Aragon, Katie Davis, Sarah Evans, Abigail Evans, and David Randall, "Thousands of Positive Reviews: Distributed Mentoring in Online Fan Communities," in Proc. of the 19th ACM Conference on Computer-Supported Cooperative Work \& Social Computing, CSCW16, (San Francisco, CA; 27 February March 2), 15 pp., 2016.

[27] John Nesbit, Karen Belfer, and John Vargo, "A convergent participation model for evaluation of learning objects," Canadian Journal of Learning and Technology/La revue canadienne de l'apprentissage et de la technologie, vol. 28, no. 3, 2002.

Available as of May 17, 2017 from https://www.cjlt.ca/index.php/cjlt/article/view/26569/19751

[28] Kati Clements, Jan Pawlowski, Nikos Manouselis, "Open educational resources repositories literature review Towards a comprehensive quality approaches framework," Computers in Human Behavior, vol. 51, part B, pp. 10981106, 2015.

Available as of May 17, 2017 from

https://doi.org/10.1016/j.chb.2015.03.026

[29] Svetlana Barnes, Fei Li, Serhiy Polyakov, Hong Xu, and William Moen, "A repository for learning objects:

Supporting the reuse and repurposing of redesigned courses and their content," in Proc. American Society for Information Science and Technology, vol. 45, no. 1, 14 pp., 2008.

[30] Dariusz Jemielniak, "Wikimedia movement governance: the limits of a-hierarchical organization," Journal of Organizational Change Management, vol. 29, no. 3, pp. 361-378, 2016.

Available as of May 17, 2017 from http://www.emeraldinsight.com/doi/abs/10.1108/JOCM-072013-0138 